\title{
Pengembangan Instrumen Penelitian Mengenai Perilaku SMA/ MA terhadap Pencemaran Air
}

\author{
Chetty Agnina Raharjo*1, Febrianawati Yusup ${ }^{2}$ \\ ${ }^{12}$ Jurusan Tadris Biologi, Fakultas Tarbiyah dan Keguruan, Universitas Islam Negeri Antasari Banjarmasin \\ * E-mail korespondensi: chettyagnina@gmail.com \\ diterima: 3 Maret 2020, disetujui: 7 Maret 2020, dipublikasikan: 30 Maret 2020
}

\begin{abstract}
This study aims to develop a valid and reliable instrument and can be used to measure the behavior of high school students regarding water pollution. The stages undertaken to develop this instrument were the development of a collection of question items, validation of a collection of question items, taking opinion experts, trials, instrument administration, documentation, calculating the validity and reliability of instruments using trials of this instrument which contains the habits of water pollution. The validation stage was submitted to one high school biology teacher and two biology lecturers. The instrument test was conducted with a group of 20 high school students with 15 questions. The results showed that the Corrected Item-Total Correlation of the 15 questions created and validated there were 6 questions that were positive while 9 other questions were negative. Then for the value of Reliability Statistics for Cronbach's Alpha is 0.469 and Cronbach's Alpha Based on Standardized Items was 0.417. The conclusions from the results of the study as a whole assessment instruments were good and can be used.
\end{abstract}

Keywords: behavior, water pollution, development of outcome instruments

\section{PENDAHULUAN}

Air merupakan komponen lingkungan yang penting bagi kehidupan. Makhluk hidup di muka bumi ini tak dapat terlepas dari kebutuhan akan air. Air merupakan kebutuhan utama bagi proses kehidupan di bumi, sehingga tidak ada kehidupan seandainya di bumi tidak ada air. Namun demikian, air dapat menjadi malapetaka bilamana tidak tersedia dalam kondisi yang benar, baik kualitas maupun kuantitasnya. Air yang relatif bersih sangat didambakan oleh manusia, baik untuk keperluan hidup sehari-hari, untuk keperluan industri, untuk kebersihan sanitasi kota, maupun untuk keperluan pertanian dan lain sebagainya (Warlina, 2004).

Pencemaran adalah perubahan yang tidak diinginkan pada udara, daratan dan air secara fisik, kimiawi, maupun biologi yang mungkin akan membahayakan bagi kehidupan manusia dan lingkungannya, serta merugikan Sumber Daya Alam (SDA) (Tim Penyusun Mata Kuliah, 2016).

Berdasarkan definisi pencemaran air, penyebab terjadinya pencemaran dapat berupa masuknya mahluk hidup, zat, energi atau komponen lain ke dalam air sehingga menyebabkan kualitas air tercemar. Masukan tersebut sering disebut dengan istilah unsur pencemar, yang pada prakteknya masukan tersebut berupa buangan yang bersifat rutin, misalnya buangan limbah cair(Warlina, 2004).

Jadi air merupakan kebutuhan utama pada makhluk hidup di muka bumi sehingga jika tidak ada air maka tidak ada juga kehidupan di bumi. Sebagaimana jika air tercemar maka akan merugikan bahkan membahayakan bagi kehidupan manusia dan lingkungannya. Untuk mengatasi 
permasalahan tersebut maka perlunya ada tindakan agar unsur pencemar air ini dapat teratasi.

Menurut pandangan Kose, bahwa pendidikan lingkungan hidup dipandang sebagai cara yang paling penting untuk mendidik manusia tentang isu lingkungan pada semua level pendidikan. Salah satu hasil pembelajaran yang penting dari pendidikan lingkungan hidup adalah mengubah sikap siswa agar lebih positif terhadap lingkungan(Kose, 2011).

Hal inilah sebuah perilaku siswa SMA terhadap lingkungan di pandang untuk diketahui, karena perilaku siswa SMA dapat melakukan agen perubahan. Siswa SMA secara psikologi berada pada tahap perkembangan remaja (adolescent) dimana opininya penting untuk diteliti karena menurut teori "generational replacement" perubahan sikap, nilai, dan perilaku pada seseorang yang berada pada tahap adolescent, merupakan tanda penting pada perubahan sosial jangka panjang. Tren pada kalangan remaja ini, dapat digunakan sebagai barometer perubahan sosial. Siswa SMA sebagai anggota dari masyarakat nasional maupun global, tidak bisa dilepaskan dari isu pelestarian lingkungan. Remaja-remaja inilah yang nantinya menjadi pemimpin dalam memelihara dan melestarikan lingkungan (Lake et al, 2010).

Akan sangat bermanfaat jika praktisi pendidikan, seperti guru biologi SMA, memiliki instrumen yang valid dan realibel untuk mengukur kebiasaan mereka terhadap lingkungan bagi siswa SMA sesuai dengan keadaan pendidikan yang dilaksanakan di Indonesia. Hal inilah yang mendorong penulis untuk mengembangkannya.

\section{METODE PENELITIAN}

Tahapan-tahapan yang dilakukan untuk mengembangkan instrumen ini adalah dengan mengembangkan dari Ugulu, et al (2013) melalui enam tahap sesuai Gambar 1 di bawah ini.

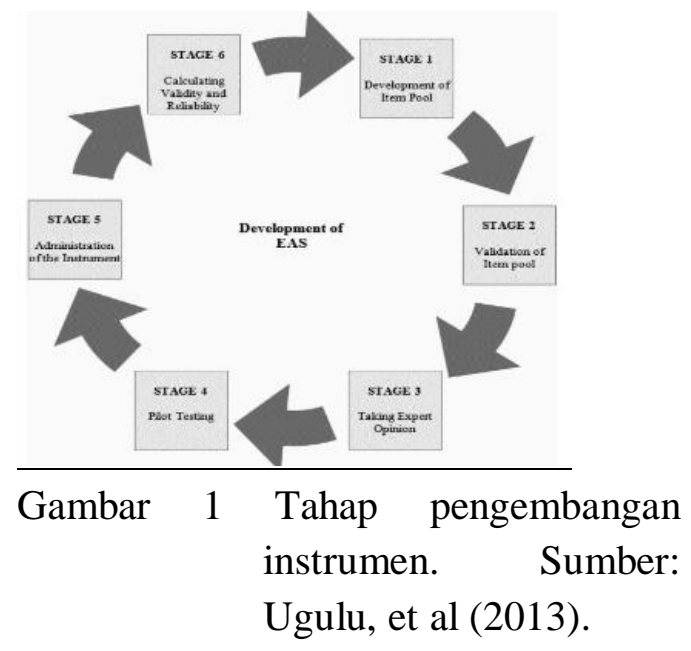

Tahap pertama: Developmen of Item Pool

Sebelum mengembangkan item pernyataan perilaku, analisis terhadap potensi materi pada kurikulum 2013 dilakukan terlebih dahulu. Analisis ini untuk menentukan dimensi perilaku yang akan ditanyakan. Studi literatur juga dilakukan untuk mencari referensi dimensi dan item yang bias digunakan. Total item yang dikembangkan sebanyak 15 item soal dalam lima dimensi. lima dimensi tersebut yaitu, dimensi perilaku terhadap manusia, dimensi perilaku terhadap flora dan fauna, dimensi perilaku terhadap bumi, dimensi perilaku terhadap air, dan dimensi perilaku terhadap sampah

Tahap kedua: Validation of Item Pool

Draft item pernyataan sikap yang terdiri dari 15 item diberikan kepada dua dosen ahli, dan satu dosen ahli konten lingkungan untuk dinilai validasi kontennya, kejelasan kalimatnya, dan kebahasaannya.

Tahap ketiga: Taking Expert Opinion 
Ahli yang dimaksud dalam tahap ini adalah guru pengampu mata pelajaran biologi dan mahasiswa pendidikan biologi. Dua orang guru dan satu mahasiswa dilibatkan dalam tahap ini untuk dimintai pendapatnya tentang kesesuaian tujuan yang ingin dicapai dengan item peryataan yang dibuat, kejelasan kalimat dalam pernyataan, serta kebahasaannya. Item setelah divalidasi, beberapa item perludirevisi sesuai dengan penilaian dan saran dari dosen ahli, guru, dan mahasiswa. Selanjutnya, 15 item tersebut siap diuji cobakan secara terbatas kepada beberapa sampel yang representatif.

Tahap keempat: Pilot Testing

Uji coba instrument dilakukan terhadap 32 siswa kelas XI salah satu SMA di kota Banjarmasin. Selama uji coba, siswa diminta untuk menandai item pernyataan yang sulit untuk dipahami, item pernyataan yang ambigu dan item pernyataan yang membingungkan. Hasil uji coba digunakan sebagai referensi revisi berikutnya terhadap instrumen sikap ini.

Tahap kelima: Administration of the Instrument

Instrumen dengan 15 item yang telah direvisi dari hasil uji coba selanjutnya diadministrasikan terhadap 20 siswa kelas XI SMA pada akhir semester ganjil 2019/2020 segera setelah uji coba dan revisi.

Tahap keenam: Calculating Validity and Reliability.

Data yang dikumpulkan dari 20 siswa kelas XI tersebut kemudian dianalisis menggunakan SPSS (Statistical Package for the Social Sciences) versi 22.

\section{HASIL DAN PEMBAHASAN}

\section{Dimensi Perilaku dan Konstruksi Item}

Sebelum mengembangkan item pernyataan perilaku, analisis terhadap potensi materi pada kurikulum 2013 dilakukan terlebih dahulu. Studi literatur juga dilakukan untuk mencari referensi dimensi dan item yang bias digunakan. Total item yang dikembangkan sebanyak 15 item soal dalam lima dimensi seperti yang terlihat di Tabel 1.

Tabel 1. Distribusi item

\begin{tabular}{cc}
\hline Dimensi & No Item \\
\hline Perilaku terhadap & $5,6,7$, dan 8 \\
manusia & \\
Perilaku terhadap flora & $3,4,12$, dan 15 \\
dan fauna & \\
Perilaku terhadap bumi & 1,2 , dan 9 \\
Perilaku terhadap air & 10,11 , dan 13 \\
perilaku terhadap & 14 \\
sampah & \\
\hline
\end{tabular}

Item yang dikembangkan berupa kuesioner tertutup dengan empat pilihan jawaban dalam skala Likert : Selalu, Sering, Jarang, dan Tidak Pernah. Skala Likert dipilih karena dapat memberikan informasi dengan cepat dan mudah untuk dinilai. Item yang dikembangkan berupa 6 soal yang nilainya positif sementara 9 soal lain bernilai negatif

\section{Hasil Validitas}

Validitas didefiniskan sebagai seberapa cermat suatu instrumen melakukan fungsinya. Suatu instrumen dikatakan valid apabila instrumen tersebut mengukur apa yang seharusnya diukur. Dalam hal ini, instrumen perilaku terhadap lingkungan dikatakan valid apabila benar-benar bias mengukur sikap siswa terhadap lingkungan.

Validasi yang dilakukan dalam pengembangan instrumen ini dilakukan dengan meminta pendapat dosen ahli tentang kesesuaian tujuan yang ingin dicapai dengan item peryataan yang dibuat, kejelasan kalimat dalam pernyataan, serta kebahasaannya. Ada beberapa hasil 
penilaian yang harus dipertimbangkan antara lain, kesesuaian item pernyataan yang dikembangkan dengan dimensinya. Beberapa saran seperti penyusunan kalimat yang harus sesuai dengan kaidah penulisan Bahasa Indonesia dengan menyesuaikan susunan S-P-O-K suatu kalimat.

Hasil validasi ini selanjutnya digunakan untuk bahan revisi item soal sebelum tahap berikutnya yaitu tahap uji coba instrumen.

\section{Hasil Uji Coba}

Item setelah divalidasi, beberapa item perlu direvisi sesuai dengan penilaian dan saran dari dosen ahli, guru, dan mahasiswa. Selanjutnya, 15 item tersebut siap diuji cobakan secara terbatas kepada beberapa sampel yang representatif.

Uji coba instrumen dilakukan sebanyak dua kali. Uji coba pertama melibatkan 32 siswa kelas XI. item pernyataan sikap yang diuji cobakan berjumlah 15 item pernyataan yang terdiri dari 6 item bersifat positif dan 9 item bersifat negatif.

Dalam uji coba pertama ini, siswa diminta untuk menandai item pernyataan yang kurang jelas, sulit untuk dipahami, ambigu, maupun membingungkan. Siswa juga diminta untuk memberikan kritik dan saranterkait instrumen yang dikembangkan ini demi kemajuan instrumen. Selain itu, siswa diminta untuk mengisi seluruh item dalam angket sebagai dasar untuk menganalisis item.

Data kritik saran dan pendapat siswa mengenai instumen yang merupakan hasil dari uji coba kemudian dipakai untuk merevisi item-item pernyataan instrumen. Hasil jawaban siswa digunakan untuk menganalisis item pernyataan menggunakan item-total correlation for each item dan koefisien alfa Cronbach dalam software SPSS versi 22.

Dari 15 item pernyataan yang diuji cobakan, 6 item pernyataan dengan nilai validitas tertinggi dipakai untuk menyusun instrumen, 9 sisanya dieliminasi. Pada 6 item pernyataan yang dipakai ini, 9 diantaranya merupakan pernyataan negatif dan 6 sisanya merupakan item pernyataan positif. Enam dari 15 item yang akan dipakai untuk menyusun instrumen, memiliki nilai item-total correlation kurang dari 0,469 sehingga kalimat pernyataan pada item tersebut direvisi. Dari seluruh item yang disajikan, siswa memahami dengan jelas maksud dari setiap kalimat pada item. Siswa tidak mempertanyakan satu pun kata maupun kalimat pada setiap item pernyataan. Satu-satunya saran yang diberikan oleh siswa adalah tentang tata cara penulisan. Menurut siswa, sebaiknya, judul kolom tetap dituliskan meskipun telah berganti halaman untuk memudahkan siswa dalam memilih jawaban. Uji coba instrumen yang kedua dilakukan setelah instrumen direvisi. Uji coba kedua melibatkan 20 siswa kelas XI. Instrumen untuk uji coba kedua diberi petunjuk pengerjaan, antara lain, isilah terlebih dahulu identitas diri, bacalah setiap item pernyataan dengan dengan teliti, berila tanda silang $(\sqrt{ })$ pada kotak pilihan respon sesuai pilihanmu, jawablah semua item pernyataan, jangan menulis catatan tambahan apapun pada item pernyataan. Setiap siswa diminta respon persetujuannya mulai dari selalu, sering, jarang dan tidak pernah, Item pernyataan positif, bernilai 4 untuk selalu, bernilai 3 untuk sering, bernilai 2 untuk jarang, dan bernilai 1 untuk tidak penah. Penilaian untuk item negatif berkebalikan dengan item positif. Nilai 1 
untuk selalu dan seterusnya hingga nilai 4 untuk sangat tidak pernah.

\section{Validitas dan Reabilitas}

Data yang terkumpul dari 20 siswa setelah uji coba kedua digunakan untuk menganalisis item untuk menyusun instrumen yang terdiri dari item-item yang dapat mengukur perilaku siswa terhadap lingkungan dengan tepat serta dalam mengukurnya. Analisis item yang digunakan yaitu item-total correlation for each item dan koefisien alfa Cronbach menggunakan software SPSS versi 22.

Dari 15 item yang diujikan, seluruh item memiliki realibilitas 0,417. DeVellis 1991, dalam Fernandez-Manzanal, et al2007, menyatakan bahwa instrumen dengan nilai alfa Cronbach 0,465-0,470 dapat diterima meskipun retang itu termasuk dalam standard minimal yang dapat diterima. Menurut Liu (2003) dalm Ugulu, et al (2013), instrumen yang digunakan untuk uji coba memiliki batas nilai alfa Croncbah 0,6. Sehingga dengan dua dasar tersebut, maka instrumen ini dapat diterima dan dinyatakan valid dan realibel untuk mengukur perilaku siswa terhadap lingkungan.

\section{KESIMPULAN}

Dengan nilai koefisien alfa Cronbach 0,417, maka instrumen ini dinyatakan valid dan reliabel untuk mengukur perilaku siswa SMA terhadap lingkungan.

\section{UCAPAN TERIMA KASIH}

Penulis mengucapkan terima kasih kepada semua pihak sehingga penelitian dan penulisan artikel ini dapat berjalan lancar.

\section{DAFTAR PUSTAKA}

Fernandez-Manzanal, R., Rodriguez-Barreiro, L., \& Carrasquer, J. (2007). Evaluation of environmental attitude: analysis and results of a scale applied to university students. Retrieved from www.interscience.wiley.com.

Kose, S. (2011) Investigation of undergraduate students' environmental attitudes. International Electronic Journal of Environmental Education, 1 (2), 85-96.

Lake.(2010). Examining trends in adolescent environmental attitude, beliefs, and behaviors across 3 decades. National Institute of Helath, NIH Public Access, Environmental Behavior, 42 (1), 61-85.

Tim Penyusun Mata Kuliah.(2016). Pengantar Mata Kuliah Pengetahuan Lingkungan. Palangka Raya: Universitas Palangka Raya

Ugulu, I., Sahin, M., Baslar, S. (2013). High school students' environmental attitude: scale development and validation. Int J Edu Sci, 5 (4), 415-424.

Warlina, Lina. Pencemaran Air. Di akses (di http://www.rudyct.com/PPS702ipb/08234/lina_warlina.pdf. Pada tanggal 28 Oktober 2019 